\title{
DOA YANG TIDAK DIJAWAB MENURUT INJIL MARKUS*
}

\section{Dany Christopher ${ }^{* *}$}

\begin{abstract}
Abstrak: Doa merupakan bagian yang tidak terpisahkan dari kehidupan orang Kristen. Namun, permasalahan muncul ketika ada doa-doa yang tidak dijawab. Ini menjadi masalah karena adanya ekspektasi bahwa suatu doa permohonan seharusnya dijawab dan dikabulkan oleh Tuhan. Artikel ini mencoba menjawab perihal bagaimana menanggapi doa-doa yang tidak dijawab. Secara spesifik, fokus analisis dari artikel ini adalah pada tiga narasi mengenai doa di Injil Markus: (1) permintaan seorang ayah (Mrk. 9:14-29), (2) permintaan Yakobus dan Yohanes (Mrk. 10:35-45), dan (3) doa Yesus di Getsemani (Mrk. 14:32-42). Teks-teks naratif dipilih karena bisa memperlihatkan dinamika dari suatu doa permohonan. Penulis akan menunjukkan bahwa salah satu fungsi utama dari narasi mengenai doa yang tidak dijawab adalah untuk membentuk kerohanian pembaca Markus (formasi spiritual).
\end{abstract}

Kata Kunci: doa, permohonan, formasi spiritual, Markus

Abstract: Prayer is an unseparable part of a Christian's life. However, problem arises when there are unanswered prayers. It is considered a problem since we expect God to answer our prayers. This article is an attempt to respond to this issue. Specifically, this article will analyze three narative texts from the Gospel of Mark: (1) the request of a father (Mark 9:14-29), (2) the request of James and John (Mark 10:35-45), and (3) the prayer of Jesus at Getshemane (Mark 14:3242). The narrative texts are chosen since they can show the dynamics

* Makalah yang dipresentasikan pada Webinar Akademik STT Amanat Agung, "Doa yang Tidak Dijawab: Perspektif dari Kitab-Kitab Injil dan Surat Yakobus," 24 Agustus 2020 di Jakarta.

** Penulis adalah rohaniwan Gereja Pemberita Injil (Gepembri) Kemurnian, Jakarta. Penulis dapat dihubungi melalui email: dany_christopher@yahoo.com. 
of a prayer request. The writer will show that one of the main functions of the narrative about prayer request is to form the spirituality of the Markan reader (spiritual formation).

Keyword: prayer, request, spiritual formation, Mark

\section{Pendahuluan}

Doa menjadi bagian yang tidak terpisahkan dari iman Kristen. Umat meyakini bahwa Allah mendengar dan menjawab doa permohonan mereka. Permasalahan muncul ketika ada doa-doa yang tidak dijawab. Hal ini menjadi masalah karena adanya ekspektasi dan pengajaran bahwa doa permohonan seharusnya dijawab. ${ }^{1}$ Artikel ini bertujuan memberi kontribusi terhadap fenomena doa yang tidak dijawab, khususnya dari Injil Markus.

Mengingat keterbatasan panjang tulisan, penulis hanya akan menganalisis tiga teks tentang doa permohonan yang tidak dijawab. Ketiga teks tersebut adalah: (1) permintaan seorang ayah (Mrk. 9:14-29), (2) permintaan Yakobus dan Yohanes (Mrk. 10:35-45), dan (3) doa Yesus di Getsemani (Mrk. 14:32-42). ${ }^{2}$ Dalam artikel ini, teks yang dipilih adalah

1. David Crump, Knocking on Heaven's Door: A New Testament Theology of Petitionary Prayer (Grand Rapids: Baker Academic, 2006), 22.

2. Dalam artikel ini, doa permohonan dipahami secara lebih luas sebagai permohonan kepada Allah Bapa maupun kepada Yesus sang Mesias. Meskipun dalam teks Markus, seseorang yang memohon kepada Yesus tidak dicatat sebagai doa permohonan, tetapi orang Kristen mula-mula sebagai pembaca kitab Markus memahami setiap permohonan kepada Yesus sebagai sebuah doa. Untuk diskusi mengenai doa kepada Yesus dalam kehidupan orang Kristen mula-mula, lihat Larry Hurtado, "The Place of Jesus in Earliest Christian Prayer and its Import for Early Christian Identity," dalam Early Christian Prayer and Identity Formation, WUNT 336, 
teks naratif. Penulis akan mencoba menganalisis dari sisi yang sedikit berbeda, yakni bukan bertanya tentang mengapa suatu doa permohonan tidak dijawab, melainkan apa fungsi dari narasi mengenai doa yang tidak dijawab. Untuk itu, teks yang dipilih bukan pengajaran Tuhan Yesus mengenai doa, melainkan narasi yang menggambarkan dinamika doa permohonan. Ketiga teks di atas dipilih karena cukup sering diangkat dalam diskusi mengenai doa yang tidak dijawab dan cukup detail dalam memaparkan dinamika antara permohonan dan penolakan. Pendekatan utama yang digunakan di sini adalah pendekatan naratif. Hal terutama yang harus diamati adalah pola-pola pengulangan di dalam teks tersebut, baik pada tataran kata, frasa, tema, maupun aksi. ${ }^{3}$ Melalui artikel ini, penulis akan menunjukkan bahwa salah satu fungsi utama dari narasi mengenai doa yang tidak dijawab adalah untuk membentuk kerohanian pembaca Markus (formasi spiritual).$^{4}$

diedit oleh Reidar Hvalvik and Karl O. Sandnes (Tübingen: Mohr Siebeck, 2014), 3556.

3. David M. Rhoads, Joanna Dewey dan Donald Michie, Mark as Story: An Introduction to the Narrative of a Gospel, edisi 3 (Minneapolis: Fortress, 2012), 4754; James L. Resseguie, Narrative Criticism of the New Testament: An Introduction (Grand Rapids: Baker Academic, 2005), 42-54; Robert Alter, The Art of Biblical Narrative (New York: Basic Books, 1981), 88-113.

4. Formasi spiritual atau pembentukan rohani dalam konteks kitab-kitab Injil terjadi karena pengenalan akan Yesus serta respons terhadap pengenalan tersebut dalam keseluruhan hidup para murid (Stephen Barton, The Spirituality of the Gospels [London: SPCK, 1992], 1-2). Dalam artikel ini konsep formasi spiritual dipakai karena dipandang lebih sesuai dengan tujuan penulisan kitab-kitab Injil. Para pembaca diharap tidak hanya memahami pengajaran yang ada tetapi juga mengalami perubahan hidup dan pertumbuhan iman di dalam Yesus. Diskusi mengenai konsep formasi spiritual dalam Perjanjian Baru bisa dilihat, misalnya, di Darrell Bock, “New 


\section{“Jika Engkau Sanggup": Permintaan Seorang Ayah (Mrk. 9:14-29)}

Konteks

Perikop ini dimulai dengan kembalinya Yesus dan ketiga muridNya dari sebuah gunung di mana peristiwa transfigurasi terjadi. Yesus melihat ada banyak orang yang berkerumun dengan murid-murid-Nya dan para Farisi (ay. 14). Ketika orang banyak itu melihat Yesus, mereka segera menemui-Nya. Saat Yesus bertanya kepada mereka apa yang terjadi, seseorang memberitahukan bahwa ia telah meminta para murid (di luar Petrus, Yohanes, dan Yakobus yang menemani Yesus ke gunung) untuk mengusir roh jahat yang merasuki anaknya, tetapi mereka gagal. Mendengar hal ini, Yesus menegur mereka sebagai "generasi yang tidak

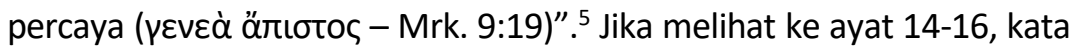
"mereka" di sini mengacu pada kelompok "orang banyak," di luar orang Farisi dan para murid. ${ }^{6}$ Sang ayah diposisikan sebagai bagian dari

Testament Community and Spiritual Formation," dalam Foundations of Spiritual Formation: A Community Approach to Becoming Like Christ, diedit oleh Paul Pettit (Grand Rapids: Kregel, 2008), 103-117; Joel B. Green, "Embodying the Gospel: Two Exemplary Practices," Journal of Spiritual Formation \& Soul Care 7.1 (2014): 11-21; Armand Barus, "Spiritualitas Surat Kolose," Jurnal Amanat Agung 12.1 (2016): 3962.

5. Kata үعveò muncul lima kali di Markus (8:12 [2x], 38; 9:19; 13:30). Pada empat kemunculan yang pertama, kata ini selalu merujuk kepada mereka yang tidak percaya kepada Yesus, atau yang berdosa dan tidak setia. Di Markus 13:30, tidak ada penjelasan tambahan mengenai identitas "generasi ini," tetapi jika disejajarkan dengan penggunaan sebelumnya, maka di 13:30 pun istilah tersebut berbicara mengenai mereka yang tidak percaya kepada Yesus.

6. Di ayat 14 ada tiga kelompok orang yang tercatat: (a) orang banyak; (b) orang-orang Farisi; dan (c) pada murid, di luar Petrus, Yohanes, dan Yakobus. Hanya orang banyak yang mendatangi Yesus dan menjadi pihak yang berdialog dengan Yesus (Sharyn E. Dowd, Reading Mark: A Literary and Theological Commentary [Macon: Smith \& Helwys, 2000], 94; John Donahue and Daniel J. Harrington, The 
kelompok orang banyak tersebut. Apa yang ia katakan mewakili kondisi dari orang banyak. Dari percakapannya dengan sang ayah, Yesus menyimpulkan bahwa yang menjadi permasalahan utama sang ayah dan orang banyak adalah ketidakpercayaan mereka. Tema ketidakpercayaan ini menjadi penting karena akan diangkat lagi dalam dinamika permintaan sang ayah kepada Yesus serta respons Yesus kepadanya.

Dinamika doa

Interaksi antara sang ayah dengan Yesus terlihat secara khusus di ayat 22-24.

Sang ayah (ay. 22): ...jika Engkau sanggup melalukan sesuatu, tolonglah kami...

Yesus (ay. 23): Katamu: jika Engkau sanggup? Segalanya mungkin/bisa bagi orang yang percaya.

Sang ayah (ay. 24): Aku percaya! Tolonglah ketidakpercayaanku ini.

Jika kita melihat interaksi antara sang ayah dengan Yesus, ada beberapa tema dan kata kunci yang diulang. Yang pertama adalah tema

Gospel of Mark, Sacra Pagina [Collegeville: Liturgical Press, 2002], 278). Beberapa sarjana berpendapat bahwa pernyataan Yesus mengenai generasi yang tidak percaya juga ditujukan kepada para murid karena mereka gagal mengusir roh jahat. Lihat misalnya, Christopher D. Marshall, Faith as Theme in Mark's Narrative, SNTSMS (Cambridge: Cambridge University Press, 1989), 117; R. T. France, The Gospel of Mark, NIGTC (Grand Rapids: Eerdmans, 2002), 365. 
mengenai kuasa. Sang ayah memulai dengan sebuah kalimat

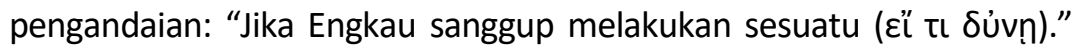
Bentuk kalimat ini menunjukkan ketidakyakinan sang ayah terhadap kemampuan Yesus. Bagi sang ayah, ada kemungkinan Yesus tidak sanggup. Bisa jadi hal ini muncul karena sebelumnya murid-murid Tuhan Yesus juga telah gagal mengusir roh jahat dan menyembuhkan anaknya. Mungkin yang muncul adalah semangat untuk tidak ada salahnya mencoba, siapa tahu berhasil. ${ }^{7}$

Ketika Yesus mendengar hal ini, la tidak serta merta mengabulkan ataupun menolak. Yesus menggunakan masa jeda yang ada untuk mengoreksi sang ayah. Hal pertama yang dikoreksi adalah sikap hati sang ayah. Pengulangan dilakukan oleh Yesus ("Jika Engkau sanggup?/દi Sủvṇ") untuk secara khusus menyasar hal ini, yakni asumsi salah sang

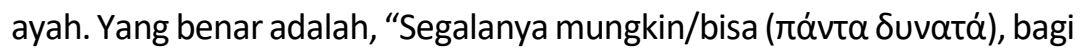
orang yang percaya." Tidak ada satu hal pun yang berada di luar jangkauan kuasa Allah. $^{8}$ Kegagalan para murid tidak mewakili kemampuan Allah. Tema kekuasaan Allah yang tak terbatas, yang dikontraskan dengan keterbatasan manusia, ditekankan sekali lagi oleh Markus di Pasal 10. Dalam percakapan dengan para murid mengenai usaha mencapai keselamatan, Yesus menyatakan bahwa meskipun bagi manusia itu adalah hal yang tidak mungkin (ádúvatov), tetapi,

7. France, Mark, 367; Camille Focant, The Gospel according to Mark: A Commentary (Eugene: Pickwick, 2012), 370.

8. France, Mark, 368; Marshall, Faith as Theme, 118. 


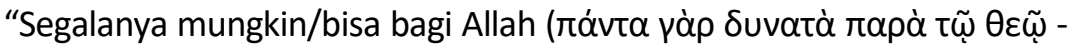
Mrk. 10:27)."

Tema kedua yang muncul adalah mengenai iman. ${ }^{9}$ Kelompok kata dengan akar kata " $\pi \iota \tau-"$ muncul empat kali di perikop ini.

9:19 ärıotos (generasi yang tidak percaya)

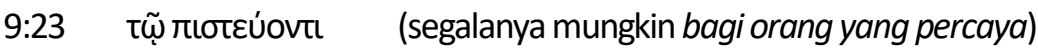

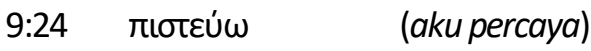

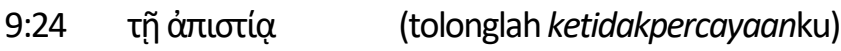

Di awal, Yesus mengkritik kelompok orang banyak, yang diwakili oleh sang ayah, sebagai generasi yang tidak beriman. Isu mengenai ketidakpercayaan mereka menjadi lebih jelas dalam percakapan di 9:2224. Sang ayah tidak yakin jika Yesus sanggup memulihkan anaknya. Yesus mengoreksi hal ini dengan menyatakan bahwa segala sesuatu mungkin bagi orang orang percaya. Permasalahan utamanya bukan di kesanggupan atau kemampuan Yesus, melainkan di keyakinan sang ayah. ${ }^{10}$ Dalam konteks doa permohonan, Yesus mengajarkan bahwa kuasa Allah hanya akan dinyatakan jika ada iman dari orang yang memohon. Tanpa iman, Allah tidak akan menyatakan kuasa-Nya. Sang ayah merespons dengan teriakan. Teriakan ini menunjukkan di satu sisi, kesungguhannya memohon dan di sisi lain, ketidakberdayaannya. Sang ayah berteriak, "Aku percaya!" karena inilah yang dituntut oleh Yesus,

9. Donahue dan Harrington, Mark, 281.

10. Kontra Crump dan Marshall, yang berpendapat bahwa pernyataan "segalanya mungkin bagi orang yang percaya," merujuk kepada iman Yesus kepada Allah (Crump, Knocking on Heaven's Door, 50; Marshall, Faith as Theme, 118-119). 
yakni beriman pada kesanggupan Allah. Meski demikian, sang ayah melanjutkan, "Tolonglah ketidakpercayaanku ini!" Di dalam satu pernyataan, sang ayah menyatakan ketidakpercayaan sekaligus kepercayaannya. Paradoks ini tentu saja menimbulkan pertanyaan bahwa jika demikian, apakah sang ayah memiliki iman atau tidak? Mungkin pertanyaan yang lebih penting untuk dijawab adalah mengapa Markus mencatat hal ini? Apa fungsi dari pertanyaan yang bersifat paradoks ini? Yang jelas, respons sang ayah menunjukkan adanya perubahan nyata dibandingkan dengan permintaannya pertama kali. Di permintaannya yang pertama, Yesus tidak mengabulkan. Namun di permintaannya yang kedua, barulah Yesus mengabulkan permohonannya dan menyembuhkan anaknya. Ini menunjukkan bahwa Yesus menerima permohonan sang ayah sebagai permohonan dengan iman - meskipun bukan iman yang kokoh. Bisa dikatakan bahwa iman sang ayah adalah iman yang rapuh, kecil, dan tidak sempurna, tetapi cukup bagi Yesus untuk menyatakan kuasa Allah. ${ }^{11} \mathrm{Hal}$ ini menunjukkan bahwa Yesus tidak menuntut kesetaraan antara besarnya iman dan besarnya kuasa yang dicurahkan. ${ }^{12}$ Bahkan iman yang rapuh pun sudah cukup.

Tema ketiga yang muncul adalah mengenai objek permohonan. Koreksi dari Yesus tidak hanya membuat sang ayah mendapatkan

11. France, Mark, 368; Adela Y. Collins, Mark: A Commentary, Hermeneia (Minneapolis: Fortress, 2007), 438; F. Scott Spencer, "Faith on Edge: The Difficult Case of the Spirit-Seized Boy in Mark 9:14-29," Review and Expositor 107 (2010): 419-424; Crump, Knocking on Heaven's Door, 52-53.

12. Crump, Knocking on Heaven's Door, 42-46. 
pemahaman yang baru. la juga memahami kondisinya. Sebelumnya ia merasa bahwa anaknyalah yang butuh pertolongan dari Yesus. Konteks permohonan minta tolong yang pertama (9:22), meski dalam bentuk jamak, menunjukkan bahwa yang butuh pertolongan langsung (menurut sang ayah) adalah si anak. Akan tetapi pada permintaan kedua, sang ayah menyadari bahwa justru dialah yang terlebih dahulu membutuhkan pertolongan (9:24). la butuh pertolongan dari Tuhan untuk bisa beriman. Jika kata yang dipakai di permohonan yang pertama adalah dalam bentuk aorist (ßońӨnбov), pada permintaan tolong yang

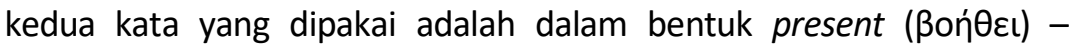
mengindikasikan adanya permohonan yang terus-menerus. ${ }^{13}$ Setelah sang ayah menyadari kondisi dirinya yang membutuhkan pertolongan untuk belajar beriman, barulah Yesus menolong anaknya.

\section{Formasi Spiritual}

Dalam konteks doa, permohonan sang ayah tidak langsung dikabulkan oleh Yesus. Dalam perikop ini, doa lebih dari hanya sekedar jawaban. Yesus memakai waktu jeda itu untuk mengoreksi dan bahkan menumbuhkan iman sang ayah. Dari dinamika doa yang "tidak dijawab," ada dua hal penting yang hendak diajarkan. Pertama, Markus mengajarkan bahwa kuasa Allah di dalam Yesus tidak terbatas. Kedua, Markus mengajarkan bahwa doa permohonan harus disertai dengan iman - kesediaan untuk percaya pada kesanggupan Yesus. Meski iman

13. Bandingkan Marshall, Faith as Theme, 121. 
yang dimiliki rapuh, hal itu tetap diperhitungkan sebagai iman. Adanya dinamika permohonan yang tidak langsung dijawab justru memungkinkan sang ayah untuk mengalami formasi spiritual. Bukan hanya si anak yang disembuhkan, tetapi iman sang ayah juga terbentuk.

\section{"Kamu Tidak Tahu Apa yang Kamu Minta": Permintaan Yakobus dan Yohanes (Mrk. 10:35-45) \\ Konteks}

Yesus dan murid-murid sedang berada dalam perjalanan menuju ke Yerusalem. Para murid berasumsi bahwa Yesus akan memerintah dan menjadi raja di Yerusalem. Ini menyebabkan Yakobus dan Yohanes mengambil kesempatan untuk berusaha mendapatkan posisi paling terhormat sebagai wakil Yesus.

Dalam Injil Markus, tema mengenai kemuliaan dan kehormatan memiliki kaitan yang erat dengan penderitaan dan kematian Yesus. Tiga pemberitahuan Yesus mengenai penderitaannya selalu diikuti oleh perikop mengenai kemuliaan dan kehormatan. ${ }^{14}$ Pada pemberitahuan Yesus yang pertama mengenai penderitaan-Nya dan implikasinya

14. Beberapa sarjana mengaitkan tema penderitaan Yesus dengan kegagalan murid untuk memahami implikasi hal tersebut dalam hidup mereka (Focant, Mark, 426; Patrick Henry Pearson, "The Cross, Sacraments and Martyrdom: An Investigation of Mark 10:35-45," St Vladimir's Theological Quarterly 36.1-2 (1992): 105-6. Jika ditelaah lebih jauh, para murid gagal memahami bahwa kerajaan Allah hanya bisa hadir melalui kematian Yesus di kayu salib. Mereka mengira bahwa Yesus akan segera memulihkan Israel dan menjadi raja. Dan ketika la menjadi raja, para murid juga akan memperoleh posisi terhormat untuk memerintah bersamaNya. 
terhadap para murid (8:31-9:1), perikop yang mengikuti adalah pemuliaan dan transfigurasi Yesus di gunung (9:2-3). Pemuliaan Yesus disaksikan oleh Petrus, Yohanes, dan Yakobus. Bisa jadi kejadian ini mendorong semangat mengejar kehormatan bagi Yakobus dan Yohanes. Pemberitahuan yang kedua dicatat di Markus 9:30-31. Seusai pemberitahuan tersebut, alih-alih bertanya mengenai makna perkataan Yesus mengenai penderitaan-Nya (9:32), para murid justru berselisih pendapat mengenai siapa yang terbesar di antara mereka (9:34). Ini menyebabkan Yesus mengajar mereka mengenai merendahkan diri dan menjadi pelayan bagi semua (9:35). Jika menarik ke belakang, di mana hanya ada Petrus, Yohanes, dan Yakobus yang diberi privilese untuk melihat pemuliaan Yesus di gunung, perdebatan para murid pasti tidak lepas dari ketiga murid tersebut. Hal ini semakin dikuatkan dengan kenyataan bahwa Yakobus dan Yohaneslah yang mengajukan permohonan untuk memperoleh posisi yang terhormat.

Pemberitahuan yang ketiga mengenai penderitaan Yesus dicatat di Markus 10:32-34. Dan segera sesudah itu, Yakobus dan Yohanes bertindak menyatakan keinginan hati mereka. Mereka sudah semakin dekat ke Yerusalem dan dalam benak mereka, ketika Yesus tiba di Yerusalem, la akan menjadi raja yang memerintah. ${ }^{15}$ Semangat kedatangan kerajaan Allah menjadi terlihat jelas pada saat Yesus tiba di Yerusalem. Di sana orang banyak bersorak: "Hosana! Diberkatilah Dia yang datang dalam nama Tuhan, diberkatilah Kerajaan yang datang,

15. France, Mark, 415; Ben Witherington III, The Gospel of Mark: A SocioRhetorical Commentary (Grand Rapids: Eerdmans, 2001), 28. 
Kerajaan bapak kita Daud, hosana di tempat yang maha tinggi!"(Mrk. 11:9-10). Yakobus dan Yohanes perlu mengamankan posisi terhormat, dengan menyingkirkan Petrus, dan murid-murid yang lain.

Dinamika doa

Permohonan Yakobus dan Yohanes dimulai ketika mereka meminta Yesus untuk mengabulkan apapun yang mereka minta dari

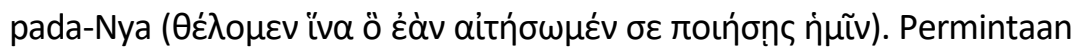
yang demikian terkesan memaksa. Bisa jadi mereka berani meminta hal tersebut karena mereka merasa memiliki privilese sebagai lingkar dalam murid Yesus. Di Markus 6, situasi yang agak mirip juga terjadi. Namun di sana raja Herodeslah, sebagai pihak yang memiliki status lebih tinggi, yang menawarkan kepada anak perempuannya, "Mintalah padaku

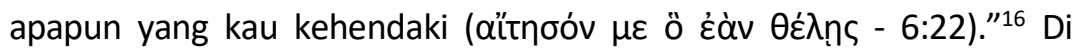
Markus 10, yang terjadi adalah sebaliknya. Yakobus dan Yohanes, sebagai pihak yang memiliki status lebih rendah, berusaha mendikte Yesus yang disamarkan dalam bentuk permohonan. Yesus kemudian menanyakan apa yang mereka kehendaki dari-Nya. ${ }^{17}$

16. Collins, Mark, 495.

17. Pertanyaan Yesus juga diajukan tidak lama dalam kisah setelah perikop ini. Di sana Bartimeus yang buta juga memohon kepada Yesus. Yesus kemudian bertanya balik apa yang ia kehendaki dari-Nya. Dalam bahasa Yunani, kedua pertanyaan Yesus memiliki kemiripan:

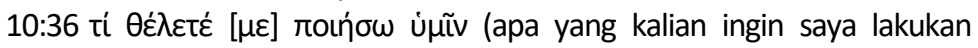
untukmu?)

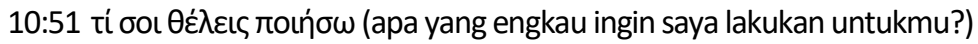
Di sana permohonan Bartimeus (untuk bisa melihat) dikabulkan. Sedangkan permintaan Yakobus dan Yohanes pada akhirnya tidak dikabulkan. Yang 
Mereka pun mengungkapkan keinginan mereka. Mereka ingin duduk dalam kemuliaan Yesus, masing-masing di sisi kanan dan sisi kiri Yesus (ay. 37). Beberapa kali Yesus menyatakan bahwa la akan datang dalam kemuliaan (8:38; 13:26). Bagi Yakobus dan Yohanes, momen kedatangan Yesus dalam kemuliaan terjadi ketika la menjadi raja di Yerusalem. Duduk di kanan dan kiri Yesus berarti menempati posisi yang paling terhormat saat memerintah bersama Yesus. ${ }^{18}$ Dengan kata lain, mereka ingin menjadi orang nomor dua dari Yesus, di atas semua muridmurid yang lain.

Di sini Yesus, sekali lagi, tidak serta-merta mengabulkan ataupun menolak permintaan mereka. Yesus memakai waktu jeda ini untuk meluruskan pemahaman kedua murid-Nya itu dan mendidik mereka. Ada dua hal yang Yesus sampaikan. Pertama, Yesus menyatakan bahwa mereka tidak mengetahui apa yang mereka minta (ay. 38). Seperti yang sudah disampaikan di atas, Yakobus dan Yohanes mengira bahwa Yesus akan menjadi raja di Yerusalem dan mereka tergoda untuk mendapatkan posisi terhormat. Akan tetapi, Yesus mengajar mereka bahwa jalan yang Yesus tempuh adalah jalan penderitaan dan penyerahan diri demi orang lain. Yesus menyampaikan pertanyaan retorik, yakni apakah mereka sanggup untuk meminum cawan

membedakan, sekali lagi, adalah isi permintaan mereka. Untuk keterkaitan antara narasi Yakobus-Yohanes dan Bartimeus, lihat Dean B. Deppe, The Theological Intentions of Mark's Literary Devices (Eugene: Wipf \& Stock, 2015), 171.

18. Collins, Mark, 495; Donahue dan Harrington, Mark, 311. Dalam peristiwa transfigurasi, Yakobus dan Yohanes melihat Yesus berbicara dengan Musa dan Elia, dua tokoh besar dalam sejarah orang Yahudi. Mungkin saja Yakobus dan saudaranya terinspirasi oleh keberadaan Musa dan Elia, dan hendak menjadi seperti mereka. 
(rotńpıov) dan menerima baptisan yang akan diterima Yesus. Di Perjanjian Lama, cawan terkadang dipakai sebagai simbol dari murka Allah yang ditujukan kepada umat-Nya atau manusia yang berdosa (Yes. 51:17, 22; Yer. 25:15-17). ${ }^{19}$ Murka Allah diekspresikan dalam bentuk hukuman nyata yang dirasakan oleh umat, antara lain berupa kekalahan perang, kematian, dan penderitaan. Meminum cawan berarti menerima murka Allah. Hal ini dikuatkan oleh permohonan Yesus di Getsemani agar Allah mengambil "cawan ini" dari-Nya sebelum la menghadapi penderitaan dan kematian salib (Mrk. 14:36). Kata "baptisan" dalam konteks perikop ini melambangkan kematian. Paling tidak, Paulus memahami baptisan Yesus dalam konteks ini (Rm. 6:3-4; Kol. 2:12). Singkatnya, Yesus bertanya apakah mereka sanggup mengikuti jalan hidup Yesus - jalan yang ditandai dengan penderitaan dan kematian. ${ }^{20}$

Mendengar pertanyaan Yesus, Yakobus dan Yohanes menyatakan kesanggupan mereka. Ada perbedaan ranah pemahaman antara Yesus dengan kedua murid-Nya. Yakobus dan Yohanes menangkap pernyataan Yesus dalam ranah literal. Yang jelas, mereka tidak menyadari apa yang harus dihadapi. Saat Yesus ditangkap, mereka ikut melarikan diri bersama-sama murid-murid yang lain (Mrk. 14:27, 50). Mereka akan menghadapi dan mengalami apa yang dialami oleh Yesus. Akan tetapi, hal ini masih belum dapat mereka pahami pada saat itu (10:39). Perbedaan perspektif ini kemudian ditegaskan kembali oleh

19. Kata yang dipakai dalam LXX adalah rotŕpıov. Lembaga Alkitab Indonesia (LAI) menggunakan istilah "piala".

20. Pearson, "The Cross," 106; Donahue dan Harrington, Mark, 311; Collins, Mark, 496; France, Mark, 416-417. 
Yesus ketika kesepuluh murid lainnya berespons keras terhadap permintaan Yakobus dan Yohanes tersebut. Yesus melanjutkan pengajaran-Nya dengan menyatakan bahwa siapapun dari mereka yang ingin menjadi yang terhormat, mereka harus menjadi pelayan dan hamba. Ini jalan hidup dari Yesus sendiri yang datang ke dunia untuk "melayani dan memberikan nyawa-Nya menjadi tebusan bagi banyak orang" (ay. 45).

Kedua, Yesus menyatakan bahwa diri-Nya tidak berhak memberi posisi di sisi kiri dan kanan-Nya, apalagi karena permintaan dari para murid. Posisi tersebut sudah disediakan kepada yang berhak (oĩ ทंtoíf $\alpha \sigma \tau \alpha \mathrm{l})$. Kata pasif di sini harus dimengerti sebagai divine passive. ${ }^{21}$ Yang berhak memberikan posisi itu adalah Allah. ${ }^{22}$ Di sini Markus memperkenalkan faktor lain dalam dinamika doa yang tidak dijawab: kehendak dan otoritas Allah. Meskipun pada akhirnya Yakobus dan Yohanes akan mengerti apa artinya mengikut Yesus dan bagaimana menjadi yang terbesar dalam perspektif kerajaan Allah, penentuan posisi terhormat di sini kiri dan kanan Yesus tetap menjadi otoritas Allah.

Formasi Spiritual

Pengajaran Yesus di sini menunjukkan adanya faktor lain dalam hal jawaban doa. Di Markus 9, kita melihat penekanan pada iman dan kuasa Allah dalam kaitannya dengan jawaban doa. Akan tetapi, perikop di sini menunjukkan bahwa iman tidak menjamin segala hal akan

21. Eugene Boring, Mark: A Commentary, NTL (Louisville: WJK, 2006), 301.

22. Donahue dan Harrington, Mark, 312. 
dikabulkan oleh Allah. Markus menekankan pentingnya perspektif yang benar. Pengikut Kristus dididik untuk tidak mencari ketenaran dan kekuasaan. Sebaliknya, mereka harus merendahkan diri dan menjadi pelayan. Mereka harus mengikuti teladan Kristus untuk melayani dan berkorban bagi orang lain (10:45). Permintaan Yakobus dan Yohanes ditolak karena mereka meminta dengan perspektif yang salah. Mereka hanya melihat pada peristiwa transfigurasi, padahal seharusnya mereka melihat pada jalan salib Yesus di Yerusalem. ${ }^{23}$ Melalui doa permohonan yang tidak dijawab, Yesus hendak mendidik mereka untuk memiliki perspektif hidup yang benar dan yang seharusnya dimiliki seorang murid Yesus: perspektif jalan salib.

Formasi spiritual lain yang diperkenalkan di sini adalah adanya hak prerogatif Allah dalam memberikan sesuatu. Hal ini akan dibahas lebih mendalam pada teks mengenai doa Yesus di Getsemani.

\section{"Janganlah Apa yang Aku Kehendaki": Doa Yesus di Getsemani (Mrk.}

\section{$14: 32-42)$}

Konteks

Getsemani adalah episode yang penting dalam perjalanan Yesus menuju salib. Getsemani adalah lokasi di mana Yesus mencurahkan kegentaran hati-Nya karena penderitaan yang menanti-Nya. Dalam

23. "Kesalahan" doa permohonan Yakobus dan Yohanes semakin kentara ketika dikontraskan dengan permohonan Bartimeus. Dalam dua insiden tersebut, Yesus menanyakan hal yang sama: apa yang mereka kehendaki agar Yesus lakukan bagi mereka $(10: 36,51)$. Permohonan Bartimeus dikabulkan, tetapi permohonan Yakobus dan Yohanes ditolak. 
perikop ini, respons Yesus menghadapi penderitaan yang akan la alami dikontraskan dengan para murid. Hal terakhir yang Yesus lakukan sebagai persiapan sebelum mengalami penderitaan salib adalah berdoa. Para murid, sebaliknya, gagal untuk berdoa dan berjaga-jaga. Hal ini menunjukkan betapa pentingnya tema doa di taman Getsemani. Dengan tidak adanya catatan mengenai Doa Bapa Kami seperti di Matius dan Lukas, maka doa yang paling menonjol dan menjadi cetak biru baru para pembaca Injil Markus adalah doa Yesus di taman Getsemani.

\section{Dinamika Doa}

Markus memakai waktu untuk memberi gambaran yang lebih detail mengenai doa Yesus. Empat kali Markus memakai kata kerja

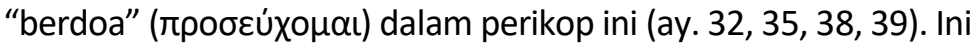
menjadi suatu indikasi bahwa tema doa memiliki peranan yang penting. Yang Markus catat pertama adalah Yesus memberi penjelasan kepada para murid bahwa la akan berdoa (ayat 32). la membawa serta Petrus dan Yakobus serta Yohanes. ${ }^{24}$

Markus dua kali menggambarkan kondisi dan isi doa Yesus: pertama melalui narator dan yang kedua melalui kalimat langsung dari Yesus. ${ }^{25}$ Rhoads menjelaskan bahwa pengulangan seperti ini merupakan bentuk two-step progression, di mana sebuah pernyataan

24. Yesus tetap membawa serta Petrus, Yakobus dan Yohanes sebagai inner circle yang menemani Dia, meskipun Yakobus dan Yohanes telah melakukan kesalahan besar dengan berusaha memperoleh posisi terhormat secara eksplisit.

25. Donahue, Mark, 408. 
dikuatkan oleh pernyataan berikutnya. ${ }^{26}$ Menurut Rhoads, pada pengulangan seperti ini, penekanan ada pada bagian kedua yang menjelaskan pernyataan di bagian pertama. ${ }^{27}$ Kita akan lihat dulu penggambaran dari kondisi Yesus (ay. 33-34),

Narator: [la] mulai merasa sangat takut dan gelisah

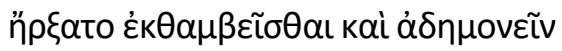

Yesus: Jiwa-Ku sangat sedih, seperti mau mati rasanya

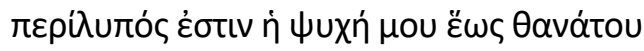

Melalui sang narator, Markus menunjukkan ekspresi emosi yang baru, yang sebelumnya tidak dicatat di Injil Markus. Pada saat Yesus sampai di Getsemani, barulah la mulai merasa ketakutan ${ }^{28}$ dan kegelisahan yang luar biasa. Hal ini diperkuat dengan pernyataan dari Yesus sendiri bahwa la mengalami kesedihan yang sangat mendalam, bagaikan mengalami kematian. Tiga kata yang dipakai di sini sangat penting. Sampai sebelum episode Getsemani, Yesus tidak pernah digambarkan sedih, gelisah, maupun takut akan apa yang ia alami. Alasan ketakutan Yesus menjadi jelas melalui isi doa Yesus (ay. 35-36),

26. Rhoads, Mark as Story, 49.

27. Rhoads, Mark as Story, 49.

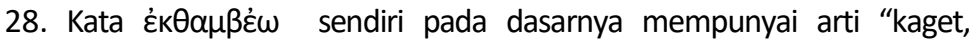
terkesima" (bdk. Mrk. 9:15; 16:5, 6). Namun di dalam konteks kisah Getsemani, istilah tersebut mengindikasikan ketakutan (France, Mark, 582). 
Narator: la...merebahkan diri ke tanah dan berdoa supaya, sekiranya mungkin, saat itu lalu dari pada-Nya.

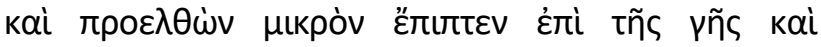

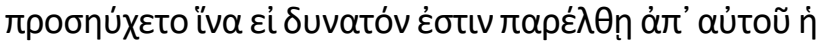
$\ddot{\omega} \rho \alpha$

Yesus: $\quad$ Ya Abba, ya Bapa, tidak ada yang mustahil bagi-Mu, ambillah cawan ini dari pada-Ku. Tetapi bukan apa yang Kukehendaki, melainkan apa yang Engkau kehendaki...

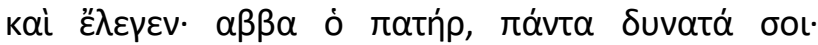

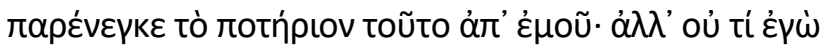

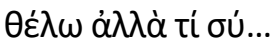

Bagian ini sekali lagi dimulai dengan penjelasan dari narator. Yesus merebahkan diri ke tanah lalu mengajukan sebuah permohonan kepada Allah Bapa di mana jikalau mungkin, Yesus dilepaskan dari momen penderitaan yang harus la alami. Meskipun Markus memakai frasa "jika

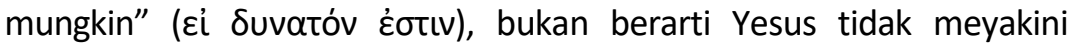
kesanggupan Allah. Yesus sendiri sudah mengajarkan bahwa segalanya mungkin bagi Allah. Yang menjadi penekanan Yesus adalah jika Allah mengizinkan.

Dasar dari permohonan Yesus menjadi jelas di ayat 36. Yesus memulai dengan sebuah pernyataan bahwa segalanya mungkin bagi Allah. Pernyataan Yesus menunjukkan bahwa la menerima sepenuhnya kemahakuasaan Allah. Pernyataan Yesus ini, dalam variasinya, juga dicatat dalam beberapa teks sebelumya. 


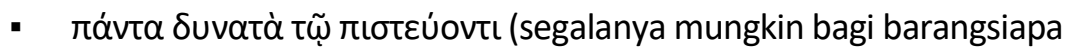
yang percaya - Mrk. 9:23)

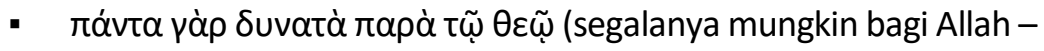
Mrk. 10:27)

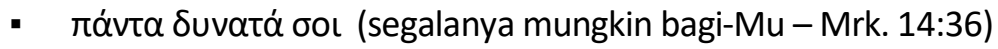

Kesanggupan ini yang menjadi dasar dari permohonan Yesus di Taman Getsemani. Yesus memohon supaya la dilepaskan dari "saat ini” ( $\dot{\eta} \omega \ddot{p} \alpha)$. Frasa "saat ini" merujuk pada saat di mana Yesus disalib. Akan tetapi, yang membuat Yesus gentar bukan semata-mata karena penderitaan salib dan kematian. Yesus memohon agar "cawan ini" diambil dari-Nya. Seperti dijelaskan sebelumnya di Markus 10, "cawan" yang harus diminum oleh Yesus melambangkan murka Allah yang tertumpah (Yes. 51:17, 22; Yer. 25:15-17). Kengerian murka inilah yang harus diterima oleh Yesus. ${ }^{29}$

Jika kita berhenti di sini, Yesus terkesan menghindar dari rencana Allah. Padahal pada masa itu, pertanyaan dan sikap Yesus saat menghadapi kematian bisa dianggap sebagai sikap yang tidak patut dimiliki oleh seorang pahlawan atau seorang pemimpin besar. ${ }^{30}$ Dalam tradisi Yahudi, para pahlawan perang Makabe menghadapi kematian dengan gagah berani (1Mak. 2:50-70; 3:58-60; 2Mak. 6:18-31; 7:1-41; $8: 21 ; 14: 37-46)$. Dalam tradisi Romawi-Yunani, beberapa filsuf pun

29. Witherington, Mark, 379.

30. Collins, Mark, 675; Boring, Mark, 398. Keduanya berargumen bahwa ketakutan Yesus adalah ketakutan yang wajar terhadap kematian karena Yesus hanya seorang manusia. 
digambarkan berani menghadapi kematian (mis: Sokrates, Zeno, dan Anaxarkus). ${ }^{31}$

Jadi mengapa hal ini dicatat di dalam Injil Markus? Seperti yang disampaikan di atas, kegentaran yang dihadapi oleh Yesus bukan semata-mata karena harus menghadapi kematian, melainkan karena harus menanggung murka Allah. Tetapi mungkin ada hal lain yang menjadi alasan mengapa kegentaran Yesus tetap dicatat meski ada risiko Yesus dianggap pengecut.

Dinamika doa Yesus memiliki fungsi didaktik. Berbagai sarjana menunjukkan bahwa pergumulan doa Yesus selaras dengan pergumulan umat percaya di berbagai teks Perjanjian Lama, terutama doa-doa ratapan dalam kitab Mazmur. ${ }^{32}$ Misalnya saja pernyataan Yesus

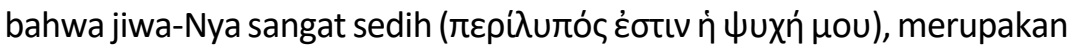

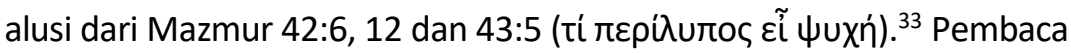
bisa mengidentifikasi pergumulan Yesus sebagai pergumulan yang mereka sendiri hadapi. ${ }^{34}$ Oleh sebab itu, doa Yesus saat dalam

31. Jan Willem van Henten dan Friedrich Avemarie, Martyrdom and Noble Death: Selected Texts from Graeco-Roman, Jewish and Christian Antiquity (London: Routledge, 2002), 25-30.

32. Mathias Nygaard, Prayer in the Gospels: Theological Exegesis of the Ideal Pray-er, Biblical Interpretation 114 (Leiden: Brill, 2012), 94; Crump, Knocking on Heaven's Door, 54-55. Donald Senior, The Passion of Jesus in the Gospel of Mark (Wilmington: Michael Glazier, 1984), 70-72. Alusi kepada Mazmur ratapan tidak terbatas pada episode di taman Getsemani, tetapi terlihat jelas dalam narasi penderitaan sampai kematian Yesus (Passion Narrative). Lihat Stephen AhearneKroll, The Psalms of Lament in Mark's Passion: Jesus' Davidic Suffering, SNTSMS 142 (Cambridge: Cambridge University Press, 2007.

33. Nygaard, Prayer in the Gospels, 94.

34. Nygaard, Prayer in the Gospels, 95; Senior, Passion of Jesus, 76. 
pergumulan menjadi cetak biru dari doa umat. Doa Yesus tidak hanya berhenti di permohonan untuk dilepaskan dari kematian dan murka, tetapi kemudian beralih ke tema yang baru: patuh sepenuhnya kepada kehendak Allah. Puncak dari doa Yesus adalah sebuah doa penyerahan, yakni bukan apa yang Yesus kehendaki, melainkan apa yang Allah Bapa kehendaki. Doa Yesus, yang semula menekankan kesanggupan dan kuasa Allah, akhirnya beralih ke penekanan pada keutamaan kehendak dan rencana Allah. Bisa dikatakan ini merupakan titik balik dari pergumulan Yesus, tatkala la menyerahkan hidup-Nya secara penuh kepada Allah. Dalam konteks Yahudi saat itu, pernyataan dalam doa Yesus merupakan ekspresi dari ketaatan yang sempurna. ${ }^{35}$

Doa Yesus di sini mencerminkan doa yang Yesus ajarkan, yakni Doa Bapa Kami (Mat. 6:9-13), terutama pada bagian "Jadilah kehendakMu." Catatan dinamika doa Yesus, dari pernyataan mengenai kesanggupan Allah dan beralih kepada ketaatan total pada kehendak Allah menunjukkan pola yang ingin disampaikan Markus kepada pembacanya. Markus ingin menekankan keutamaan dari kehendak dan rencana Allah. Prioritas kehendak Allah sudah diperkenalkan di awal Injil Markus, ketika Yesus mendefinisi ulang siapa sesungguhnya yang menjadi saudara-Nya dan ibu-Nya, yaitu mereka yang "Melakukan kehendak Allah" (Mrk. 3:35). Keutamaan kehendak Allah dalam pengajaran dan hidup Yesus berbanding terbalik dengan Yakobus dan

35. Collins, Mark, 679. Ekspresi pergumulan dari Yesus juga selaras dengan pergumulan umat Tuhan di Perjanjian Lama (lihat Angela K. Harkins, "Ritualizing Jesus' Grief at Gethsemane," Journal for the Study of the New Testament 4.2 (2018): 189-192. 
Yohanes dalam doa permohonan mereka di Markus 10:35. Di sana mereka memaksa Yesus secara halus untuk mengabulkan apa yang menjadi keinginan mereka sendiri. Bagi mereka, prioritas utama adalah apa yang mereka, sebagai manusia, inginkan. Di Getsemani, yang terjadi adalah sebaliknya. Yesus mengesampingkan kehendak-Nya, dan tunduk sepenuhnya pada kehendak Allah Bapa.

Meskipun Allah sanggup dan segalanya mungkin bagi-Nya, tetapi Allah bisa saja menghendaki hal yang berbeda dari apa yang kita inginkan. Bisa dikatakan bahwa iman kepada Allah bukan hanya iman kepada kuasa Allah. Iman kepada Allah juga berarti, dan bahkan lebih utamanya lagi, iman kepada kehendak dan rencana Allah. Ini menjadi alasan teologis mengapa doa Yesus di Getsemani dicatat dengan segala pergumulannya. ${ }^{36}$

Formasi Spiritual

Doa Yesus di Getsemani menjadi cetak biru bagi umat, tidak hanya dalam berdoa, tetapi juga dalam memahami jawaban doa. Dalam perikop sebelumnya Yesus menekankan kesanggupan dan kuasa Allah. Tetapi di Getsemani ada elemen lain yang lebih utama, yakni kehendak Allah. Ada peralihan dari memohon sesuai keinginan diri menjadi memohon dan berserah sesuai keinginan dan rencana Allah. Dengan kata lain, kehendak Allah lebih utama dibanding kehendak manusia.

36. Crump, Knocking on Heaven's Door, 59. 
Selain itu, doa Yesus di Getsemani mengajarkan bahwa kuasa Allah tidak bisa dilepaskan dari kehendak Allah. Dengan demikian, iman dalam doa bukan hanya sebatas iman pada Allah yang mahakuasa, ${ }^{37}$ tetapi berarti juga mempercayakan hidup kepada rencana dan kehendak Allah. Jika ditarik lebih jauh, ini menjadi acuan bagi umat yang menderita sebagai pengikut Kristus yang mungkin mempertanyakan mengapa Allah tidak menolong mereka, padahal Allah maha kuasa. Sebagaimana Yesus berserah penuh, demikian pula para pengikut-Nya diajar untuk berserah dan percaya sepenuhnya pada kehendak dan rencana Allah. ${ }^{38}$

\section{Kesimpulan}

Kita sudah melihat tiga narasi mengenai doa permohonan yang tidak dijawab. Kesimpulan utama dari ketiga narasi tersebut ada pada perbedaan perspektif atau penekanan. Doa yang tidak dijawab merupakan bagian dari pertumbuhan rohani seorang pengikut Yesus. Perspektif dinamika doa dan formasi spiritual menunjukkan bahwa respons utama terhadap doa yang tidak dijawab bukanlah bahwa doa tersebut salah dan berhenti di sana. Doa yang tidak dijawab bukan pula berarti Allah tidak sanggup atau lemah. ${ }^{39}$ Yesus dan Allah menggunakan

37. Nygaard, Prayer in the Gospels, 96.

38. France menyatakan bahwa perpaduan antara keyakinan pada kuasa Allah dan ketaatan pada kehendak Allah menyebabkan terjadinya "dinamika yang misterius" dalam doa. Asumsi bahwa doa pasti dijawab asal kita mengikuti metode atau langkah-langkah tertentu adalah keliru (France, Mark, 585).

39. Crump, Knocking on Heaven's Door, 304. 
doa yang tidak dijawab sebagai bagian kehidupan Kristen dari proses pembentukan rohani (formasi spiritual).

Masing-masing perikop yang dibahas di atas mengajarkan satu elemen proses pembentukan rohani yang diharapkan. Melalui doa yang sepertinya tidak dijawab, umat belajar untuk: (1) percaya sepenuhnya kepada kuasa Tuhan yang tak terbatas; (2) memiliki perspektif hidup yang benar - yang selaras dengan cara hidup Yesus; dan (3) menerima serta berserah sepenuhnya pada keutamaan kehendak Allah dalam hidup umat percaya.

\section{Daftar Pustaka}

\section{Buku}

Ahearne-Kroll, Stephen. The Psalms of Lament in Mark's Passion: Jesus' Davidic Suffering. SNTSMS 142. Cambridge: Cambridge University Press, 2007.

Alter, Robert. The Art of Biblical Narrative. New York: Basic Books, 1981.

Barton, Stephen. The Spirituality of the Gospels. London: SPCK, 1992. Bock, Darrell. "New Testament Community and Spiritual Formation." Dalam Foundations of Spiritual Formation: A Community Approach to Becoming Like Christ. Diedit oleh Paul Pettit, 103117. Grand Rapids: Kregel, 2008.

Boring, Eugene. Mark: A Commentary. New Testament Library. Louisville: WJK, 2006.

Collins, Adela Yarbro. Mark: A Commentary. Hermeneia. Minneapolis: Fortress, 2007.

Crump, David. Knocking on Heaven's Door: A New Testament Theology of Petitionary Prayer. Grand Rapids: Baker Academic, 2006.

Deppe, Dean B. The Theological Intentions of Mark's Literary Devices. Eugene: Wipf \& Stock, 2015. 
Donahue, John R., dan Daniel J. Harrington. The Gospel of Mark. Sacra Pagina. Collegeville: Liturgical Press, 2002.

Dowd, Sharyn E. Reading Mark: A Literary and Theological Commentary. Macon: Smith \& Helwys, 2000.

Focant, Camille. The Gospel according to Mark: A Commentary. Eugene: Pickwick, 2012.

France, R. T. The Gospel of Mark. NIGTC. Grand Rapids: Eerdmans, 2002.

Hurtado, Larry. "The Place of Jesus in Earliest Christian Prayer and its Import for Early Christian Identity." Dalam Early Christian Prayer and Identity Formation. Diedit oleh Reidar Hvalvik and Karl O. Sandnes, 35-56. WUNT 336. Tübingen: Mohr Siebeck, 2014.

Marshall, Christopher D. Faith as a Theme in Mark's Narrative. Cambridge: Cambridge University Press, 1989.

Nygaard, Mathias. Prayer in the Gospels: Theological Exegesis of the Ideal Pray-er. Biblical Interpretation 114. Leiden: Brill, 2012.

Resseguie, James L. Narrative Criticism of the New Testament: An Introduction. Grand Rapids: Baker Academic, 2005.

Rhoads, David M., Joanna Dewey dan Donald Michie. Mark as Story: An Introduction to the Narrative of a Gospel. Edisi 3. Minneapolis: Fortress, 2012.

Senior, Donald. The Passion of Jesus in the Gospel of Mark. Wilmington: Michael Glazier, 1984.

van Henten, Jan Willem, dan Friedrich Avemarie. Martyrdom and Noble Death: Selected Texts from Graeco-Roman, Jewish and Christian Antiquity. London: Routledge, 2002.

Witherington III, Ben. The Gospel of Mark: A Socio-Rhetorical Commentary. Grand Rapids: Eerdmans, 2001.

\section{Jurnal}

Barus, Armand. "Spiritualitas Surat Kolose." Jurnal Amanat Agung 12.1 (2016): 39-62, https://doi.org/10.47754/jaa.v12i1.160.

Green, Joel B. "Embodying the Gospel: Two Exemplary Practices." Journal of Spiritual Formation \& Soul Care 7.1 (2014): 11-21, https://doi.org/10.1177/193979091400700103. 
Grindheim, Sigurd. "'Everything is Possible for One who Believes" Faith and Healing in the New Testament." Trinity journal 26 (2005): 11-17.

Harkins, Angela K. "Ritualizing Jesus' Grief at Gethsemane." Journal for the Study of the New Testament 4.2 (2018): 177-203, https://doi.org/10.1177\%2F0142064X18804433.

https://doi.org/10.1177\%2F003463731010700313.

Reardon, Patrick Henry. "The Cross, Sacraments and Martyrdom: An Investigation of Mark 10:35-45." St Vladimir's Theological Quarterly 36.1-2 (1992): 103-115.

Spencer, F. Scott. "Faith on Edge: The Difficult Case of the SpiritSeized Boy in Mark 9:14-29." Review and Expositor 107 (2010): 419-424. 